\title{
АНАЛІЗ БАЛАНСОВОЇ НАДІЙНОСТІ ЕЛЕКТРОЕНЕРГЕТИЧНИХ СИСТЕМ 3 ВІДНОВЛЮВАНИМИ ДЖЕРЕЛАМИ ЕНЕРГІЇ
}

Ю.П. Матеєнко, канд. техн. наук, доцент, Р.В. Вожаков, асистент

Національний технічний університет України «Київський політехнічний інститут імені Ігоря Сікорського», 03056, просп. Перемоги, 37, м. Київ, Україна

Впровадження альтернативних джерел енергї в енергосистеми дозволяе знизити шкідливий вплив на довкілля від традищійних джерел генерачії, але має і ряд недоліків. Насамперед ие нестабільне генерування відновлюваних джерел енергії (ВДЕ) через залежність від погодних умов, що породжує для електричних мереж $і$ енергосистеми в цілому ряд нетипових проблем. Отже, виникає необхідність вдосконалення засобів системної автоматики з метою узгодження електропостачання від ВДЕ та мережевих підстанцій енергосистеми. Вплив ВДЕ на режими районних електричних мереж залежить від значення сумарного розосередженого генерування в ній, від одиничної встановленої потужсності ВДЕ, а також від їх місия приєднання до електричної мережи.

Традииійний підхід до оцінки оптимальної конфігурачії полягає у забезпеченні балансової надійності або адекватності системи генерації. При цььому на периий план виходять показники забезпечення попиту. Однак при оцінці економічних показників енергосистеми, щэо використовують ВДЕ, треба зважати також на раціональне використання виробленої електроенергії.

В статті розглянуто базові показники (індекси) відповідності генерування стосовно спожсивання, такі як очікування втрати навантаження, імовірність втрати навантаження, частота втрати навантаження, тривалість втрати навантаження. Значення показника балансової надійності повинно вибиратися на основі визначення того рівня надійності забезпечення потреб споживачів в електроенергії, при якому додаткові витрати на його підвищення для енергосистеми стануть вище, ніж компенсація імовірнісного рівня збитків споживачів. Бібл. 6.

Ключові слова: відновлювані джерела енергї̈, електроенергетична система, балансова надійність, показники забезпечення nonumy.

\section{ANALYSIS OF BALANCE RELIABILITY OF ELECTRIC POWER SYSTEMS WITH RENEWABLE ENERGY SOURCES}

Y. Mateienko, candidate of technical sciences, associate professor, R. Vozhakov, teaching fellow

National Technical University of Ukraine «Igor Sikorsky Kyiv Polytechnic Institute»,

03056, 37 Peremogy Av., Kyiv, Ukraine.

The introduction of alternative energy sources in power systems can reduce the harmful effects on the environment from traditional generation sources, but also has a number of disadvantages. First of all, it is the unstable generation of renewable energy sources (RES) due to the dependence on weather conditions, which creates a number of atypical problems for electrical networks and the power system as a whole. Therefore, there is a need to improve the means of system automation in order to coordinate the power supply from RES and network substations of the power system. The influence of RES on the modes of district electric networks depends on the value of the total dispersed generation in it, on the unit installed capacity of RES, as well as on their place of connection to the electric network.

The traditional approach to estimating the optimal configuration is to ensure the balance reliability or adequacy of the generation system. At the same time, indicators of supply demand come to the fore. However, when assessing the economic indicators of energy systems using RES, it is also necessary to take into account the rational use of generated electricity.

The article considers the basic indicators (indices) of compliance of generation in relation to consumption, such as loss of load expectation, loss of load probability, loss of load frequency, loss of load duration. The value of the balance reliability indicator should be chosen on the basis of determining the level of reliability of meeting the needs of consumers in electricity, at which the additional cost of increasing it for the power system will be higher than compensation for the probable level of consumer losses. Ref. 6.

Keywords: renewable energy sources, electric power system, balance reliability, indicators of demand supply. 


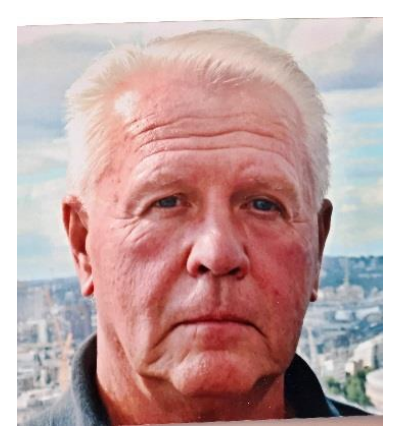

Ю.П. Матеєнко Y. Mateienko

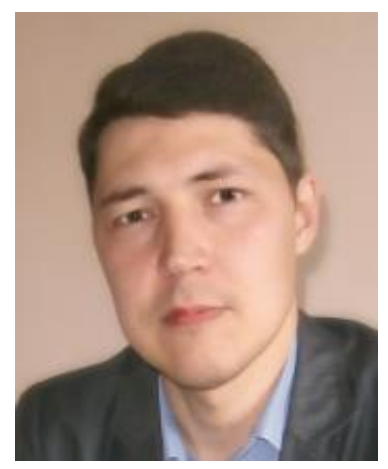

P.В. Вожаков R. Vozhakov
Відомості про автора: доцент кафедри відновлюваних джерел енергії Національного технічного університету України «Київський політехнічний інститут імені Ігоря Сікорського», кандидат технічних наук

Освіта: Київський політехнічний інститут, інженер-електрик за спеціальністю «Електричні станції»

Наукова сфера: дослідження з питань підвищення надійності об'єктів електроенергетики та забезпечення енергетичної безпеки в умовах роботи енергоринку

Публікації: 72

ORCID: 0000-0002-4798-6853

Контакти: +38(044)206-28-09

e-mail: myurix@ukr.net

Відомості про автора: асистент кафедри відновлюваних джерел енергії Національного технічного університету України «Київський політехнічний інститут імені Ігоря Сікорського»

Освіта: НТУУ «КПІ», магістр електротехніки, спеціальність «Електричні станції»

Наукова сфера: системи підтримки прийняття рішення з управління ресурсом силового електрообладнання електричних станцій

Публікації: 28

ORCID: 0000-0001-8534-6227

Контакти:+38(044)406-82-33

e-mail: vozhakovr@fea.kpi.ua
Author information: Associate Professor of the CDepartment of Power Stations of the National Technical University of Ukraine «Igor Sikorsky Kyiv Polytechnic Institute» (Igor sikorsky KPI), PhD of Technical sciences Education: Kyiv Polytechnic Institute, engineer-electrical on the specialty «Power Stations»

Reasearch area: Investigation of the problems of improving the reliability of electric facilities and ensuring energy security in the operating conditions of the energy market

Publications: 72

ORCID: 0000-0002-4798-6853

Contacts: +38(044)206-28-09

e-mail: myurix@ukr.net

Author information: Teaching Fellow of the Department of Renewable Energy of the National Technical University of Ukraine «Igor Sikorsky Kyiv Polytechnic Institute»

Education: NTUU "Kyiv Polytechnic Institute", master of electrical engineering, specialty «Power Plants»

Reasearch area: Decision support systems for resource management of power electrical equipment of power plants

Publications: 28

ORCID: 0000-0001-8534-6227

Contacts: +38(044)406-82-33

e-mail: vozhakovr@fea.kpi.ua

\section{Bcmyn. Електрична енергія, яка} генерується відновлюваними джерелами енергії, вітровими (BEC) та сонячними електростанціями (CEC), носить імовірнісний характер. Впродовж доби потужність таких типів електростанцій може змінюватись від максимального до мінімального значення не один раз. Для надійного забезпечення споживачів електричною енергією в електроенергетичній системі (ЕЕС) повинен зберігатись баланс активної потужності, тобто генерація електричної енергії повинна дорівнювати споживанню. Щоб забезпечити такий баланс, EЕС повинна мати певну кількість генерувальних потужностей, які можуть змінювати свою робочу потужність відповідно до зміни навантаження (зростання чи зменшення). Збільшення в балансі ЕЕС частки електростанцій негарантованої потужності від ВДЕ може призвести до зростання варіативності навантаження балансувальних електростанцій, де виникає проблема балансування активної потужності. Якщо регулювальний діапазон або швидкості реагування балансувальних електростанцій на зміни навантаження ЕEC недостатньо надійні та швидкі, це може спричинити виникнення дефіциту потужності й позначитись на надійності забезпечення електричною енергією споживачів.

В енергетичній стратегії розвитку відновлювальних джерел енергії в Україні до 2035 року планується стрімке нарощування встановленої потужності ВДЕ, тобто завдання зберегти балансову надійність в умовах зростання частки ВДЕ в ЕЕС України $є$ досить актуальним. 
За результатами досліджень, проведених Міжнародним агентством 3 відновлюваних джерел енергії (IRENA) у січні 2017 року, Україна володіє найбільшим серед країн Південно-Східної Європи технічним потенціалом впровадження відновлюваних джерел енергії. За оцінками експертів, загальний річний потенціал ВДЕ складає більше 1 млн ГВт·год. (без урахування великих гідроелектростанцій). На відновлювані джерела енергії- вітер та сонячну радіацію - припадає понад $90 \%$ цього потенціалу.

Впровадження альтернативних джерел енергії в електроенергетичних системах, крім зниження шкідливого впливу на довкілля i вирішення проблем, що пов'язані з забрудненням відходами під час виробітку електричної енергії, знизить використання природних ресурсів та розвантажить системоутворювальні й розподільні лінії електропередачі. Однак відновлювальні джерела енергії мають і ряд недоліків. Оскільки електричні мережі проєктувалися в умовах централізованого електропостачання, то розбудова в них ВДЕ породжує нетипові для попереднього періоду проблеми і питання. Передусім велику роль відіграє нестабільне генерування ВДЕ через залежність від погодних умов. Отже виникає необхідність вдосконалення систем релейного захисту та автоматики 3 метою узгодження електропостачання від ВДЕ та живильних підстанцій електроенергетичної системи. Вплив ВДЕ на режими районних електричних мереж суттєво залежить від значення сумарного розосередженого генерування в ній, від одиничної встановленої потужності ВДЕ та їх типу, а також від їх місця під'єднання в електричній мережі (це можуть бути шини нижчої напруги підстанцій або відгалуження ліній електропередачі).

Мета роботи. Оцінка надходження енергії від відновлюваних джерел енергії (ВДЕ) i їx вплив на показники балансової надійності електроенергетичних систем (ЕЕС).

Виклад основного матеріалу. Оцінка оптимальності побудови ЕЕС потребує критеріїв, що характеризували б відповідність поставленим вимогам. Традиційний підхід до оцінки правильності конфігурації потужностей полягає у забезпеченні балансової надійності або адекватності системи генерації. Загалом можна розглядати баланс потужності та баланс енергії, хоча ці фізичні величини пов'язані. При цьому на перший план виходять показники забезпечення попиту. Однак, оцінюючи економічні показники енергосистем, що використовують ВДЕ, потрібно зважати також на раціональне використання виробленої енергії. Отже, індекси ефективності енергосистеми мають стосуватися режимів, при яких можливою $є$ недостатня потужність генерації (втрата навантаження чи споживання) та коли генерація $\epsilon$ надлишковою (втрата енергіi). Базовими показниками адекватності генерування щодо рівня споживання вважаються такі індекси, як очікувана втрата навантаження LOLE (loss of load expectation), імовірність втрати навантаження LOLP (loss of load probability), частота втрати навантаження LOLF (loss of load frequency) та тривалість втрати навантаження LOLD (loss of load duration), a також індекс очікуваної недоданої енергії EENS (expected energy not served) [1, 2]. Обсяг недоданої енергії через невідповідну генерацію визначається такими індексами, як очікувана 
втрата енергії $L O E E$ (loss of energy expectation) чи імовірність втрати енергії LOEP (loss of energy probability).

Існують різні підходи до визначення вказаних індексів. Концептуально вони визначаються такими виразами:

$$
L O L E=\sum_{i \in S} p_{i} T_{i}
$$

де $p_{i}$ - ймовірність перебування системи в $i$-му стані, $S$ - множина всіх станів системи, що асоціюються 3 втратою навантаження, $T_{i}-$ тривалість стану (дискретність за часом). Зазвичай $L O L E$ - це середня кількість днів чи годин за певний період (зазвичай за рік), коли навантаження перевищують досяжну потужність генерації. I хоча цей показник не відображає ні обсягу, ні частоти появи дефіциту потужності, він $\epsilon$ широко вживаним індексом.

Інший схожий показник, що застосовується при вивченні надійності енергосистемиймовірність втрати навантаження LOLP. Це прогнозована кількість часу в довгостроковій перспективі, коли очікуване навантаження буде більшим, ніж потужність наявних генерувальних потужностей. Одне 3 формулювань цього індексу [1]:

$$
L O L P=\sum_{j \in S} P\left[C_{j}\right] \cdot P\left[L_{j}>C_{j}\right],
$$

де $P[\cdot]-$ імовірність певної потужності, $C_{j}-$ досяжна в $j$-й відрізок часу генерована потужність, $L_{j}-$ навантаження.

Індекси (1) та (2) пов'язані залежністю:

$$
L O L E=L O L P \cdot T, T=\sum_{i} T_{i} .
$$

Такі індекси вважаються допоміжними:

$$
L O L F=\sum_{i \in S}\left(F_{i}-\psi_{i}\right),
$$

де $F_{i}$ - частота виходу системи зі стану $i, \psi_{i}-$ частка переходів, що не спричиняе змін стосовно втрати чи збереження навантаження.

Здебільшого LOLF має розмірність кількості випадків на рік. Середня очікувана тривалість втрати навантаження:

$$
L O L D=L O L E / L O L F
$$

Слід зазначити, що індекси $L O L P$ чи $L O L E$ не відображають сумарний дефіцит потужності, який виникає в моменти, коли відбуваються відключення споживачів. Крім того, важливо усвідомлювати, що години LOLE не є часом, протягом якого відбувається серйозне відключення, яке залишає цілі ринкові зони без енергіï.

Популярний показник втрати навантаження - індекс очікуваної відсутності енергії EENS (expected energy not served) або EUE чи $E E U$ (expected unserved energy) [3, 4]. Якщо відома крива тривалості навантаження (в осях «час-потужність»), то площа під цією кривою представляє енергію, що використовується в конкретному розглянутому періоді. Маючи імовірний розподіл генерованої потужності, можна обчислити очікуваний обсяг недопоставленої енергії. Результат такого підходу зазвичай представляється як імовірне співвідношення між фактичною нестачею живлення і енергією, необхідною системі. Це відношення, як правило, невелике число, називають індексом ненадійності енергії. Практичніший варіант отримують шляхом віднімання індексу ненадійності від одиниці. Кінцевий показник відомий як індекс надійності енергії. Нехай імовірність недостатньої потужності на $k$-му інтервалі часу позначено $p k$; втрачена внаслідок дефіциту енергія 
навантаження, як недовиконана робота, дорівнює $E k$. Тоді ймовірна втрачена (недопоставлена) енергія LOEE (loss of energy expectation) дорівнює $p_{k} E_{k}$, а очікувана втрата енергії за певний період розраховується як:

$$
L O E E=\sum_{k \in S} p_{k} E_{k}
$$

Як правило, обирається розмірність «МВт·год/рік». Нормалізований індекс визначається діленням на загальну спожиту енергію.

$$
L O E E_{n}=\sum_{k=1}^{n} \frac{p_{k} E_{k}}{E_{\Sigma}}, E_{\Sigma}=\sum_{t=0}^{T} E_{L}(t) \cdot \Delta t,(7)
$$

де $\Delta t$ - елементарний часовий інтервал; $n-$ кількість часових інтервалів (при часовій дискретності «год/рік» $n=8760$, для «днів/рік» $n=385)$, що застосовується як показник відповідності застосування формули.

Індекс надійності енергіï $E I R$ (energy index of reliability) розраховується так:

$$
E I R=1-L O E E_{n} .
$$

Існують також інші способи оцінки надійності енергозабезпечення.

При плануванні розвитку ЕEC ключове значення має забезпечення балансової надійності або адекватності системи генерації 3 урахуванням пропускних спроможностей системоутворювальної мережі, тобто її здатність забезпечувати покриття попиту в електричній потужності та енергії заданої якості при планових та очікуваних (вірогідних) простоях елементів ЕЕС. Як основні критерії для оцінки адекватності $[5,6]$, можуть використовуватись:

- математичне очікування річного обсягу обмежень споживачів електричній енергії $M[\Delta W]$, (аналогами є EUE або LOEE, МВт·год/рік);

- відносне задоволення споживачів електричною енергією $\pi=1-M[\Delta W] / L_{T}\left(L_{T}-\right.$ попит споживачів на електричну енергію протягом часу $T$ );

• інтегральні ймовірності появи дефіциту потужності (Јд);

• ймовірність втрати навантаження (в.о.) LOLP;

- середнє число днів дефіциту потужності, тобто тривалості втрати навантаження, діб в рік ( $L O L E$, інше позначення - LOLE 365$)$;

• середнє число годин дефіциту потужності в рік, іноді називають тривалістю втрати навантаження в годинах за рік (LOLH, інше позначення $\left.-L O L E_{8760}\right)$.

Перший 3 перерахованих показників належить до іменованих, інші - до відносних. При цьому показник $\pi$ малочутливий до збурень $\mathrm{i}$ несе практично ту саму інформацію, що i показник $M[\Delta W]$, тільки у відносних одиницях. 3 погляду раціональності прийнятих рішень щодо розвитку ЕЕС відносні (ймовірні) показники балансової надійності більш інформативні.

Для оцінки наявності дефіциту потужності в загальному випадку необхідно здійснити оптимізацію режиму за мінімумом загальної вартості спожитої електроенергії з формалізацією балансів виробництва-споживання, тобто мінімізації витрат палива. При їх проведенні вважається, що обмеження на можливість використання доступної потужності генерації відсутні, за винятком ВEC і CEC, яка задається випадковим чином 3 певного діапазону. Потужність споживачів переважно вибирається 3 певного діапазону випадковим чином. При виникненні дефіциту генерації диспетчерська служба ОЕС вживає заходів для його усунення, тобто неможливо розглядати стан ОЕС в певний 
час конкретної доби як незалежний від суміжних. Отже, для коректного розрахунку LOLH необхідно використання складної методології $з$ урахуванням усіх чинників. Тому критерій $L O L E$ сьогодні є найбільш використовуваним у світі для оцінки балансової надійності.

Значення показника балансової надійності повинно вибиратися на основі визначення того рівня надійності покриття потреб споживачів в електроенергії, при якому додаткові витрати на його підвищення для ОЕС стають більшими, ніж компенсація імовірнісного рівня збитків споживачів. Так, у колишньому СРСР імовірнісний норматив надійності у вигляді $J \partial=0,004$ мав саме таке обгрунтування, яке базувалось на зіставленні додаткових витрат на підвищення надійності енергопостачання та економічних втрат споживачів від перерви в електропостачанні. Звісно, такий підхід потребує постійного корегування значень показників балансової надійності під впливом зміни вартості додаткової генерації, необхідної для покриття дисбалансів в умовах лібералізованого ринку електроенергії, та рівня збитків від переривів в електропостачанні у окремих груп споживачів. Саме тому в розвинених країнах показники надійності не мають свого економічного обгрунтування. На основі експертних оцінок прийняті їх певні значення, що служать індикаторами вибору рішень щодо забезпечення належного рівня надійності ОЕС. Так, загальноприйнятий стандарт середнього числа днів дефіциту потужності LOLE у багатьох розвинених країнах дорівнює 0,1 діб/рік або 1 добі в 10 років (США), у Франції $L O L H=3$ год/рік, у Великій Британії $L O L H=4$ год/рік, в Ірландії $L O L H=8$ год/рік [5].
Висновки.

Потенціал

розвитку відновлюваних джерел енергії на ринку електроенергії України досить великий, оскільки 3 кожним роком відсоток ВДЕ в енергосистемі значно зростає і потрібно правильно оцінювати та оптимізувати графік завантаження таких потужностей, мінімізувати втрати в мережі, покращити якість напруги й отримувати дохід від продажі електричної енергії та потужності.

1. Billinton R. Reliability Assessment of Electric Power Systems Using Monte Carlo Methods. Springer Science+Business Media. LLC. 1994. 361 p.

2. Кузнєцов М.П., Лисенко О.В., Мельник О.А. Особливості стохастичної оптимізації гібридних енергосистем на базі ВДЕ. Відновлювана енергетика. 2018. № 2. C. 6-15.

3. Okinda V.O. A review of techniques in optimal sizing of hybrid renewable energy systems. IJRET. International Journal of Research in Engineering and Technology. 2015. № 11. Pp. 153-163.

4. Reliability Standard Methodology. Annex C. Department of Energy\&Climate Change. [Електронний pecypc]. URL: https://assets.publishing.service.gov.uk/governme nt/uploads/system/uploads/attachment_data/file/223653/emr_con sultation_annex_c.pdf.

5. Чукреев Ю.Я., Чукреев М.Ю. Сравнительный анализ вероятностных показателей балансовой надежности и методических принципов их определения при управлении развитием электроэнергетических систем. Известия Коми научного центра УрО РАН. 2012. № 3(11). С.76-81.

6. Interim Report of the Sector Inquiry on Capacity Mechanisms, Report from the Commission, Brussels. [Електронний ресурc]. URL: https://ec.europa.eu/competition/s ectors/energy/capacity_mechanism_report_en.pdf.

\section{REFERENCES}

1. Billinton R. Reliability Assessment of Electric Power Systems Using Monte Carlo Methods. Springer Science+Business Media. LLC.1994. 361p. [in English].

2. Kuznietsov M., Lysenko O., Melnyk A. Osoblyvosti stokhastychnoyi optymizatsiyi hibrydnykh enerhosystem na bazi VDE. [Features of stochastic optimization for hybrid power 
systems with the renewable sources]. Vidnovluvana energetika. 2018. No. 2. Pp. 6-15. [in Ukrainian].

3. Okinda V.O. A review of techniques in optimal sizing of hybrid renewable energy systems. IJRET. International Journal of Research in Engineering and Technology. 2015. No. 11. Pp. 153-163. [in English].

4. Reliability Standard Methodology. Annex C. Department of Energy\&Climate Change. [Electronic resource]. URL:_data/file/223653/emr_consultation_annex_c.pdf .

(Applying date: 20.05.2021). [in English].

5. Chukreev Yu.Ya., Chukreev M.Yu. Sravnitelnyy analiz veroyatnostnykh pokazateley balansovoy nadezhnosti i metodicheskikh printsipov ikh opredeleniya pri upravlenii razvitiyem elekt-roenergeticheskikh sistem. [Comparative analysis of probabilistic indicators of balance reliability and methodological principles of their determination when managing the development of electric power systems]. Izvestiya Komi nauchnogo tsentra UrO RAN. 2012. No. 3(11). Pp. 76-81. [in Russian].

6. Interim Report of the Sector Inquiry on Capacity Mechanisms. Report from the Commission. Brussels. [Electronic resource]. URL: https://ec.europa.eu/competition/sec tors/energy/capacity_mechanism_report_en.pdf. (Applying date: 20.06.2021). [in English].

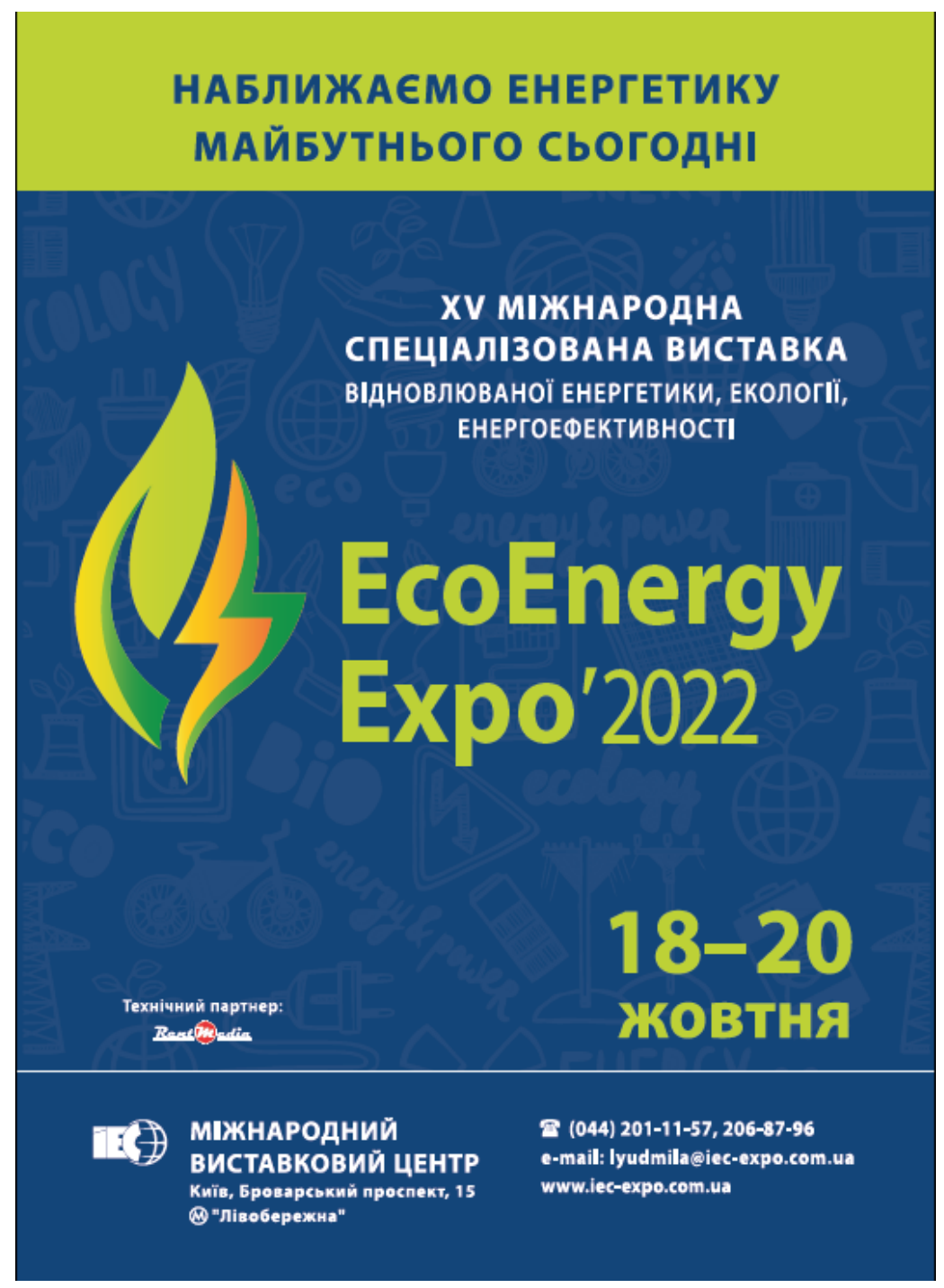

